\title{
New Insights into the Implication of Epigenetic Alterations in the EMT of Triple Negative Breast Cancer
}

\author{
Noura Khaled *(D) and Yannick Bidet ${ }^{(D)}$ \\ Laboratoire d'Oncologie Moléculaire, Centre Jean PERRIN et IMoST, UMR 1240, Inserm/Université Clermont \\ Auvergne 58 rue Montalembert, 63000 Clermont-Ferrand, France; yannick.bidet@uca.fr \\ * Correspondence: Noura.KHALED@uca.fr
}

Received: 5 February 2019; Accepted: 11 April 2019; Published: 18 April 2019

check for updates

\begin{abstract}
Breast cancer is the most common cancer and leading cause of cancer death among women worldwide, encompassing a wide heterogeneity of subtypes with different clinical features. During the last two decades, the use of targeted therapies has emerged in clinical research in order to increase treatment efficiency, improve prognosis and reduce recurrence. However, the triple negative breast cancer (TNBC) subtype remains a clinical challenge, with poor prognosis since no therapeutic targets have been identified. This aggressive breast cancer entity lacks expression of oestrogen receptor (ER) and progesterone receptor (PR), and it does not overexpress human epidermal growth factor receptor 2 (HER2). The major reason for TNBC poor prognosis is early therapeutic escape from conventional treatments, leading to aggressive metastatic relapse. Metastases occur after an epithelial-mesenchymal transition EMT of epithelial cells, allowing them to break free from the primary tumour site and to colonize distant organs. Cancer-associated EMT consists not only of acquired migration and invasion ability, but involves complex and comprehensive reprogramming, including changes in metabolism, expression levels and epigenetic. Recently, many studies have considered epigenetic alterations as the primary initiator of cancer development and metastasis. This review builds a picture of the epigenetic modifications implicated in the EMT of breast cancer. It focuses on TNBC and allows comparisons with other subtypes. It emphasizes the role of the main epigenetic modifications lncRNAs, miRNAs, histone and DNA- modifications in tumour invasion and appearance of metastases. These epigenetic alterations can be considered biomarkers representing potential diagnostic and prognostic factors in order to define a global metastatic signature for TNBC.
\end{abstract}

Keywords: triple negative breast cancer TNBC; epithelial-mesenchymal transition EMT; epigenetic modifications; long non-coding RNAs LncRNAs; miRNAs; histone modifications; DNA methylation; metastasis

\section{Introduction}

Although mortality associated with breast cancer has been constantly declining over the last 20 years, there were still more than 626,000 deaths worldwide in 2018 (International Agency for Research on Cancer IARC 2018 Breast Cancer Statistics). A major reason for these therapeutic failures is the wide heterogeneity of breast cancer and distant metastases. Fifteen years ago, molecular classification of these cancers paved the way for targeted therapeutic approaches taking into account the specificities of different subtypes of breast cancer [1,2]. 
Triple Negative Breast Cancer (TNBC) is a highly aggressive subtype, accounting for $10-20 \%$ of all diagnosed breast cancers, with no targeted therapy available due to the lack of oestrogen and progesterone receptor expression and the absence of HER2 amplification [3]. Representing a serious clinical therapeutic challenge, TNBC is characterized by poor overall survival, early relapse and most importantly, frequent distant metastasis [3]. A lethal hallmark of cancer, metastasis of TNBC is correlated with aberrant activation of epithelial-mesenchymal transition (EMT) [4,5]. EMT is a fundamental biological mechanism by which epithelial cells acquire a mesenchymal phenotype by gaining migratory and invasive properties and modifying cell adhesion molecules $[4,5]$. This differentiation process is important during development, but inhibiting EMT by antagonizing the EMT-related mesenchymal cell markers such as $\alpha \mathrm{v} \beta 3$ integrin reveals its massive involvement in TNBC aggressiveness and metastasis [6]. It allows triple negative epithelial breast cancer cells to break free from their primary tumour site and eventually to colonize distant organs developing metastasis [4,5]. During the last decade, a large amount of data and knowledge were acquired on TNBC biomarkers. Chemokine C-C motif ligand 5 (CCL5), interleukin 17B, transforming growth factor $\beta$ (TGF- $\beta$ ), placental growth factor, CXCL10 and platelet-derived growth factor receptor $\beta$ (PDGFR $\beta$ ) were considered as biomarkers for TNBC aggressiveness and progression. These biomolecules were involved in the recruitment of bone marrow-derived mesenchymal stem cells (BM-MSCs), which play a crucial role in multiple EMT program mechanisms (cell migration and invasion, neo-angiogenesis, promoting extracellular matrix remodelling ... ), towards TNBC sites [7]. Cancer-associated EMT requires complex and comprehensive reprogramming, including changes in metabolism, expression levels and epigenetic $[4,5]$.

From a molecular point of view, EMT is characterized by the loss of E-cadherin, claudin and cytokeratin expression, and the overexpression of N-cadherin and vimentin, which are respectively epithelial and mesenchymal cell markers [5]. Partial EMT leads to cells with a mixed phenotype, called "metastable". Several major pathways are involved in the EMT, including TGF- $\beta$, NF- $\mathrm{kB}$, WNT, $\mathrm{NOTCH}, \mathrm{HIF} 1 / 2$ and RAS-ERK1/2. Most of these interact with transcription factors implicated in the modulation of E-cadherin expression such as Snail, Slug, ZEB1, ZEB2, E47, Twist, and KLF8 [5].

As researchers continue to illustrate the effect of epithelial-mesenchymal plasticity on tumour progression and to investigate its invasion-related molecular mechanism, a clearer perception of the general epigenetic modifications in malignant cells undergoing EMT is now appearing. Nevertheless, the current state of art of the precise role of epigenetic regulators in controlling both EMT and MET processes in tumorigenesis including TNBC are not fully understood yet. In sharp contradiction with EMT inducing factors and transcription factors, we are just now beginning to understand how those alterations induce EMT and MET or function to maintain epithelial and mesenchymal phenotypes. For this reason, the exact epigenetic regulation remains a frontier to discover.

We hypothesize that close interactions between different EMT inducing factors and TFs and epigenetic regulators exist. EMT-related factors and markers are targets of epigenetic regulations. Epigenetic modifiers must also be regulated by TFs to transcriptionally regulate epithelial and mesenchymal genes during EMT. For example, TFs may be responsible for the expression of epigenetic factors activating or repressing in return the expression of EMT-markers. The understanding of these probable functional interactions controlling the inter-conversion between epithelial and mesenchymal phenotypes may provide new opportunities and novel therapeutic approaches aiming towards the prevention of cancer invasion and metastasis, based on the development of individualized epigenetic cancer therapy.

A lot of work has been published on TNBC, and mutations and modifications of expression levels are now well described. In our review, we would discuss the current state-of-the-art and latest findings regarding the implication of epigenetic modifications in EMT. We would emphasize on the role of four major epigenetic modifications in the regulations of the EMT of TNBC responsible for distant metastases, describing the various molecular pathways implicated as well as a large number of transcription factors influenced by the deregulation of these factors. They include non-coding RNA, 
both long-non-coding RNAs (lncRNAs) and micro RNA (miRNAs), and modifications at the level of histones or DNA, such as acetylation or methylation.

For each class of epigenetic factors (lncRNA, miRNA, histone or DNA modification), we first present large screening studies that provide lists of candidates specifically dysregulated in TNBC. These general studies pave the way for targeting TNBC through the identification of high impact candidate genes and factors. However, from one study to another, the sets of genes often overlap poorly, and functional validation is required. Thus, in the second part of each chapter, we focus on studies describing the role of epigenetic factors involved in the EMT of TNBC. The functional evidences are not paraphrased for each factor, but they are gathered in Tables 1-5 and a comprehensive network assembles all interactions in Figure S1 (Supplementary Material). Further genes are pending for validation in order to identify novel prognostic factors and therapeutic targets. A number of essential anti-TNBC drugs used (Table 4) and a description of primary applied clinical trials are discussed in this paper.

\section{Long Non-Coding RNAs}

Long non-coding RNAs (lncRNAs) are transcribed RNA molecules not encoding any protein, with a length over 200 nucleotides [8]. Due to the lack of experimental tools and overall knowledge, the function of lncRNAs was largely unknown until the early 1990's when H19 and Xist were found to be involved in epigenetic modulations [9]. Since the publication of the human genome in 2001 and the finding that only $2 \%$ of the genome encodes for proteins despite the fact that $>90 \%$ is actively transcribed [10], extensive attention has been given to long non-coding RNAs in order to investigate their biological and regulatory activity. While considering that dysregulation of lncRNAs is well described in many human disorders, such as cardiovascular disease [10], prior investigations have shown that dysregulation of lncRNAs plays a critical role in cancer progression, as oncogenic or tumour-suppressor genes by modulating tumour cell death, proliferation, migration, invasion and drug resistance [11]. In recent years, researchers were highly interested in the role of lncRNAs in several subtypes of breast cancer including TNBC [12-16]. LncRNAs have been reported as promising diagnostic biomarkers, prognostic factors and potentially efficient therapeutic targets by a set of systematic research described further down. Moreover, these studies have evaluated the role of single lncRNAs for different endpoints, such as overall survival OS, progression-free survival PFS, poor prognosis, and TNBC proliferation and metastasis.

Lately, abnormal expression of lncRNAs, related altered mechanisms and primary deregulation were the subject of pivotal studies presented later.

In a microarray analysis study, a set of 1403 unique lncRNAs, with 853 up-regulated and 550 down-regulated, was discovered to be differentially expressed between TNBC and non-tumourous tissues, suggesting a pivotal role of lncRNAs in TNBC progression [17]. In the aim of offering specific therapeutic targets and promising diagnosis biomarkers, a core group of onco-lncRNAs was identified. Another set of 1211 differentially expressed TNBC-specific lncRNAs among the wide dysregulated lncRNAs was defined by co-expression networks [18].

Furthermore, a lncRNA expression signature of four lncRNAs (IGKV, RP11-434D9.1, BC016831, and LINC00052) differentially expressed between TNBC and non-TNBC tissues was validated [19]. Recently, a re-mapping strategy generated novel data allowing the discovery of additional differentially expressed lncRNAs in TNBC. Sixty one recent lncRNAs were identified, where thirty-three lncRNAs were downregulated (Top five: $\operatorname{lnc}$-PAPLN-2:1, lnc-FLT3LG-1:7, $\operatorname{lnc}$-NEK8-2:1, $\operatorname{lnc}-F L O T 2-1: 1$ and $\operatorname{lnc}$-ZNF75D-2:2) and twenty eight lncRNAs were upregulated (Top five: $\operatorname{lnc}$-DNAJC16-1:1, lnc-SC5DL-3:1, Inc-PURA-2:1, lnc-EIF2C2-1:1 and lnc-ELP4-3:1) [20]. 
From our intention to review the recent advances in this field evaluating the crucial role of each lncRNA in a single study separately in the outcome of the 'invasion-metastasis cascade' in TNBC patients, a set of EMT specific lncRNAs are presented. IncRNAs involved in EMT of TNBC could be assigned to two classes based on the level of expression and molecular regulation. First, lncRNAs LET [21], Xist [22], IncRNA-CTD-2108O9.1 [23], and GAS5 [24] were shown to be downregulated in TNBC cell lines. Upregulation of these lncRNAs attenuates TNBC cell proliferation and viability and enhances apoptosis. In addition, the overexpression of these lncRNAs inhibits TNBC growth, invasion and migration, and represses EMT by increasing E-cadherin expression as well as decreasing $\mathrm{N}$-cadherin and Vimentin expression. The mechanisms by which this category of lncRNA acts differ from one lncRNA to another. XIST exerts its suppressive activity via miR-155/CDX1 [22], GAS5 by functioning as a competing endogenous RNA (ceRNA) that antagonizes miR-196a-5p targeting thereby FOXO1/PI3K/AKT signalling [24], $\operatorname{lncRNA-CTD-210809.1~targets~leukemia~inhibitory~factor~receptor~}$ LIFR [23], while no specific molecular mechanism for LET is yet defined [21]. (see Figure S1 and Table 1).

Twenty-three different lncRNAs investigated in separated studies were reported to be pro-tumoural agents, usually correlated with a high capacity of TNBC progression and metastasis, poor overall survival and early outcome. Knockdown of these upregulated TNBC lncRNAs leads eventually to the suppression of cell motility along with TNBC metastasis and invasion and to the inhibition of EMT molecular marker expression. The mechanisms of actions of these lncRNAs, MALAT1 [25-27], HOTAIR [28], SNHG12 [29], LINC01638 [30], H19 [31], Linc-ZNF469-3 [32], LINC00673 [33], Inc-ATB [34], HOXA11-AS [35], OR3A4 [36], MIAT [37], GHET1 [38], AC026904.1/UCA [39], NNT-AS1 [40], PVT1 [41], ARNILA [42], IncRNA-RoR [43], LINC00518 [44], ADAM/lnc015192 [45], LOC554202 [46], and snaR [47] are summarized in Table 1 (see Figure S1).

Among these two profiles, some lncRNAs, GAS5 [24], MIAT [37], ARNILA [42], NNT-AS1 [40], lnc015192 [45], and UCA [39] are able to directly regulate EMT pathways and TNBC invasion by functioning as ceRNAs for EMT-regulating-RNA via sharing common sequences with them (see Figure S1 and Table 1). 
Table 1. Significant lncRNAs implicated in EMT of TNBC.

\begin{tabular}{|c|c|c|c|c|c|}
\hline IncRNAs & Targets & Genes and Pathways Implicated & Sense of Dyregulation in TNBC & Role of LncRNA in TNBC & References \\
\hline LET & & & Downregulated & Anti-tumoural & [21] \\
\hline XIST & miR-155 & CDX1 & Downregulated & Anti-tumoural & [22] \\
\hline IncRNA-CTD-2108O9.1 & LIFReceptor & JAK/STAT and MAPK pathway & Downregulated & Anti-tumoural & [23] \\
\hline GAS5 & miR-196a-5p & FOXO1/PI3K/AKT pathway & Downregulated & Anti-tumoural & [24] \\
\hline \multirow[t]{2}{*}{ MALAT1 } & miR-1 & Slug & Up-regulated & Pro-tumoural & [25] \\
\hline & miR-129-5p & - & Up-regulated & Pro-tumoural & [26] \\
\hline MALAT1/HuR (ELALV1) complex & - & CD133 & Absence of complex & Anti-tumoural & [27] \\
\hline SNHG12 & & MMP13 & Up-regulated & Pro-tumoural & [29] \\
\hline LINC01638 & & $\begin{array}{c}\text { c-Myc } \\
\text { MTDH-Twist1 pathway } \\
\end{array}$ & up-regulated & Pro-tumoural & {$[30]$} \\
\hline H19 & $\mathrm{miR}-675$ & ubiquitin ligase E3 family (c-Cbl and Cbl-b) & Up-regulated & Pro-tumoural & [31] \\
\hline Linc-ZNF469-3 & miR-574-5p & ZEB1 & Up-regulated & Pro-tumoural & [32] \\
\hline LINC00673 & & NCR3LG1(B7-H6) & Up-regulated & Pro-tumoural & [33] \\
\hline Lnc-ATB & miR-141-3p & ZEB1 and ZEB2 & Up-regulated & Pro-tumoural & [34] \\
\hline HOXA11-AS & & & Up-regulated & Pro-tumoural & [35] \\
\hline OR3A4 & & & Up-regulated & Pro-tumoural & [36] \\
\hline GHET1 & & & Up-regulated & Pro-tumoural & [38] \\
\hline AC026904.1 and UCA (ceRNA) & & Slug & Up-regulated & Pro-tumoural & [39] \\
\hline $\begin{array}{c}\text { NNT-AS1 } \\
(c e R N A)\end{array}$ & miR-142-3p & ZEB1 & Up-regulated & Pro-tumoural & [40] \\
\hline PVT1 & & $\mathrm{P} 21$ & Up-regulated & Pro-tumoural & [41] \\
\hline ARNILA (ceRNA) & miR-204 & Sox4 & Up-regulated & Pro-tumoural & [42] \\
\hline LncRNA-RoR & miR-145 & ARF6 & Up-regulated & Pro-tumoural & [43] \\
\hline LINC00518 & & CDX2 and Wnt signaling pathway & Up-regulated & Pro-tumoural & [44] \\
\hline ADAM and $\operatorname{lnc} 015192(c e R N A)$ & miR-34a & & Up-regulated & Pro-tumoural & [45] \\
\hline LOC554202 & & & Up-regulated & Pro-tumoural & [46] \\
\hline snaR & & & Up-regulated & Pro-tumoural & [47] \\
\hline
\end{tabular}




\section{MiRNAs}

MicroRNAs (miRNAs) are small noncoding RNAs approximately 22 nucleotides long, involved in the regulation of posttranscriptional gene expression [48]. Aberrant miRNA expression has been associated with cancer cell progression, invasion and metastasis, acting both as oncogenes and tumour suppressors [49-55]. miRNAs are also powerful drivers of metastasis in many malignancies by regulating non-EMT-related and/or EMT-related mechanisms [56].

As miRNAs are smaller and more stable than mRNAs in formalin-fixed paraffin-embedded (FFPE) tissues and accessible body fluids, their expression was the subject of multiple investigations mentioned later, as potential TNBC biomarkers in order to give insight into their role in TNBC progression and invasion along with the appearance of distant metastasis. A number of general studies evaluating a panel of miRNAs by different technics are described lately.

Recently, using the robust rank aggregation (RRA) method, metasignatures of six significantly dysregulated miRNAs: two downregulated: $h s a-m i R-449 a$ and $h s a-m i R-190 b$ and four upregulated: $h s a-m i R-9-5 p$, hsa-miR-18a-5p, hsa-miR-135b-5p and hsa-miR-522-3p, were identified from different studies, with high prediction accuracy. The gene ontology analysis revealed the top 10 preferred target genes and 10 pathways of metasignature miRNAs in TNBC suggesting promising candidate for diagnostic biomarkers in TNBC [57].

Four miRNA signatures in TNBC given by $m i R-155, m i R-493, m i R-30 e$ and $m i R-27 a$ expression levels were identified allowing a new stratification of TNBC based on the level of patient outcome. Defined as "risk"-associated, down-regulation of $m i R-27 a$ and $m i R-30 e$ is correlated with worse patient outcome, while upregulation of $m i R-493$ and $m i R-155$ associated with better outcome is described as "protective" [58].

Furthermore, miRNAs expression profile generated by limma algorithm identified 67 significantly differentially expressed miRNAs (DEmiRNAs) between TNBC and normal tissues. Among them 21 were down-regulated (Top five: hsa-mir-486-1, hsa-mir-486-2, hsa-mir-4732, hsa-mir-139 and hsa-mir-451a) and 46 up-regulated (Top five: hsa-mir-105-1, hsa-mir-519a-1, hsa-mir-105-2, hsa-mir-767 and hsa-mir-516a-1) [59].

Further profiling of miRNAs expression in TNBC cells identified four candidate miRNAs (miR-26a, miR-153, miR-10b and miR-146a) as potential TNBC biomarkers. Exogenous expression assays reported that miR-26a and miR-10b suppress BRCA1 expression in MDA-MB-231 and MCF-7 cells, while BRCA1 expression was downregulated by miR-153 only in MCF7 cells. High expression of miR-146a in TNBC cells compared to non-TNBC was validated by in silico analysis of The Cancer Genome Atlas (TCGA) data [60].

Seven other miRNAs (miR-300, miR-382, miR-494, miR-495, miR-539, miR-543, and miR-544) in the imprinted DLK1-DIO3 region are known to cooperatively repress EMT. DLK1-DIO3 miRNAs target EMT-inducing molecules repressing a signaling network comprising ZEB1/2, TWIST1, BMI1, and miR-200 family miRNAs. Thus, silencing the cluster by hypermethylation of upstream CpG islands in MDA-MB-231 cells represents a key early step that promotes loss of CDH1 expression, initiates EMT, and activates tumour cell invasion and metastasis [61]. Three main members ( $m i R-200 a, b$ and $c$ ) of the miR200 family are considered as tumour suppressor miRNAs restraining EMT. These miRNAs targeting E-cadherin suppressors ZEB1, ZEB2 and SUZ12 are downregulated in TNBC cells, representing a promising therapeutic target [62-64] (see Figure S1 and Table 2).

Given that many lncRNAs act as competing endogenous lncRNA (ceRNA) to sequester miRNAs, and since miRNAs rank among the main drivers of EMT in many malignancies, this report aims to generate a general summary of all miRNAs differentially expressed in TNBC, as promising new therapeutic targets and novel molecular biomarkers for TNBC. Several data suggest that chromatin modifications are correlated with differential expression of lncRNAs and miRNAs in TNBC. Promoter hypermethylation was shown to be one of the major mechanisms to silence miR-200c/miR-141 and LOC554202/miR-31 locus [46,64]. It is very likely that the same regulation occurs with other lncRNAs and miRNAs involved in the EMT of TNBC. 
Table 2. Major miRNAs involved in EMT of TNBC.

\begin{tabular}{|c|c|c|c|c|}
\hline miRNAs & Targets and Pathways & Sense of Dyregulation in TNBC & Role of miRNA in TNBC & References \\
\hline miR-31 & & Downregulated & Anti-tumoural & [46] \\
\hline DLK1-DIO3 region (miRs 300, 382, 494, 495, 539, 543, and 544) & TWIST1, BMI1, ZEB1/2, and miR-200 family & Downregulated & Anti-tumoural & [61] \\
\hline miR200a & $\begin{array}{c}\text { ZEB1, ZEB2 and SUZ12 } \\
\text { E-cadherin pathway } \\
\text { EPH receptor A2 (EPHA2) } \\
\text { EPHA2 pathway } \\
\end{array}$ & Downregulated & Anti-tumoural & {$[62]$} \\
\hline miR200b & $\mathrm{PKC} \alpha / \operatorname{Rac} 1$ & Downregulated & Anti-tumoural & [63] \\
\hline miR-200c & ZEB1 & Downregulated & Anti-tumoural & [64] \\
\hline miR-30a & Inhibition of ROR1 & Downregulated & Anti-tumoural & [65] \\
\hline miR-146a & Inhibition of RhoA & Downregulated & Anti-tumoural & [66] \\
\hline miR-143-3p & $\begin{array}{l}\text { LIMK1 expression } \\
\text { LIMK1/CFL1 pathway }\end{array}$ & Downregulated & Anti-tumoural & [67] \\
\hline miR-200b-3p/miR-429-5p & $\begin{array}{c}\text { LIMK1 expression } \\
\text { LIMK1/CFL1 pathway } \\
\end{array}$ & Downregulated & Anti-tumoural & {$[68]$} \\
\hline miR-139-5p & TGF- $\beta$, Wnt, MAPK, and PI3K & Downregulated & Anti-tumoural & [69] \\
\hline $\operatorname{miR}-212-5 p$ & $\begin{array}{c}\text { Prrx2 } \\
\text { Wnt/ } \beta \text {-catenin pathway }\end{array}$ & Downregulated & Anti-tumoural & {$[70]$} \\
\hline miR-199a-5p & & Downregulated & Anti-tumoural & [71] \\
\hline miR-155 & & Downregulated & Anti-tumoural & [72] \\
\hline $\operatorname{miR}-34 c-3 p$ & $\begin{array}{c}\text { MAP3K2 } \\
\text { MAP3K2 pathway }\end{array}$ & Downregulated & Anti-tumoural & [73] \\
\hline miR-3178 & Notch1 & Downregulated & Anti-tumoural & [74] \\
\hline miR-200b-3p & & Downregulated & Anti-tumoural & [75] \\
\hline $\operatorname{miR}-125 b$ & $\begin{array}{c}\text { MAP2K7 } \\
\text { MAPK pathway }\end{array}$ & Downregulated & Anti-tumoural & [76] \\
\hline miR-655 & Prrx1 & Downregulated & Anti-tumoural & [77] \\
\hline miR27-a & $\begin{array}{c}\text { PTEN, PKB } \\
\text { PI3K/AKT pathway }\end{array}$ & Up-regulated & Pro-tumoural & {$[78]$} \\
\hline $\operatorname{miR}-182$ & $\begin{array}{c}\text { Inhibition of FOXF2 } \\
\text { PFN1 } \\
\end{array}$ & $\begin{array}{l}\text { Up-regulated } \\
\text { Up-regulated }\end{array}$ & $\begin{array}{l}\text { Pro-tumoural } \\
\text { Pro-tumoural }\end{array}$ & $\begin{array}{l}{[79]} \\
{[80]}\end{array}$ \\
\hline $\operatorname{miR}-454$ & $\begin{array}{c}\text { PTEN } \\
\text { PI3K/AKT pathway }\end{array}$ & Up-regulated & Pro-tumoural & [81] \\
\hline $\operatorname{miR}-373$ & $\begin{array}{c}\text { HIF1 } \alpha \text { and TWIST } \\
\text { HIF1 } \alpha \text {-TWIST pathway }\end{array}$ & Up-regulated & Pro-tumoural & [82] \\
\hline $\operatorname{miR}-221 / 222$ & $\begin{array}{c}\text { ADIPOR1 and TRPS1 } \\
\text { NF-kB, IL6, and JAK2/STAT3 pathway }\end{array}$ & Up-regulated & Pro-tumoural & [83] \\
\hline miR-10b & TGF- $\beta 1$-induced EMT pathway & Up-regulated & Pro-tumoural & [84] \\
\hline
\end{tabular}


Among the numerous miRNAs identified by these large screening assays, single studies aiming to investigate the precise performance of some specific miRNAs in the EMT of TNBC were proceeded. The goal was to determine the level of miRNAs expression in TNBC highly metastatic cells in vitro and to alter this expression. The analysis of epithelial and mesenchymal markers was used to determine the anti- or pro-metastatic role of the candidate miRNAs. For a number of these miRNAs, target genes were predicted and tested in order to identify the specific mechanism of action of the miRNAs.

A set of twenty two miRNAs correlated with EMT and TNBC cell migration and invasion suggesting a leading role in influencing the expression levels of their target genes and pathways can be established: miR-30a [65], miR-146a [66], miR-143-3p [67], miR-200b-3p/miR-429-5p [68], miR-139-5p [69], miR-212-5p [70], miR-199a-5p [71], miR-155 [72], miR-34c-3p [73], miR-3178 [74], miRNA-200b-3p [75], $m i R-125 b$ [76], and miR-655 [77], were outlined as down regulated while miR27-a [78], miR-182 [79,80], $m i R-454$ [81], $m i R-373$ [82], $m i R-221 / 222$ [83], and miR-10b [84] were reported as up regulated (see Figure $\mathrm{S} 1$ and Table 2).

\section{Histone Modifications}

$\mathrm{N}$-terminal modifications of histones, including acetylation and methylation, as well as the reverse of these processes frequently observed in cancer, are responsible for modifying the secondary DNA structure and the accessibility of transcription factors to gene promoter regions regulating gene transcription [85-87]. In breast cancer, histones modifications play a major role in cell proliferation, induced apoptosis and metastatic ability [88].

Discussing histone modifications mechanisms in TNBC especially, surveys proposed an interesting performance for histones modifications in the appearance and progression of TNBC [89-91]. Despite the not fully understood effect of histones alterations, histone modification inhibitors, such as histone deacetylase inhibitors (HDACis) have emerged as a promising new class of multifunctional anticancer agents preventing TNBC growth and metastasis [92]. These inhibitors could also help to better understand the effect of histone modifications on the outcome and the metastasis of TNBC through gene expression regulation in order to define new biomarkers and targeted therapies [92,93]. Nonetheless, two HDACis used together with ionizing radiation, autophagy and kinase inhibitors were the subject of multiple investigations [94-96].

Identifying major histone alteration's delineation in TNBC as well as principle genes influenced by these modifications is the subject of upcoming surveys. A specific histone modification profile identified eight key histone modifications (H3K9me3, H3K9ac, H3K27ac, H3K4me3, H3K27me3, H3K4me1, H3K36me3 and H3K79me2) in four different TNBC cell lines (MDA-MB-231, MDA-MB-468, MDA-MB-436, and HCC1937) among thirteen cell lines [97]. Intriguingly, a TNBC specific gene was also identified: Actin Filament Associated Protein Antisense RNA 1 (AFAP1-AS1), an anti-sense lncRNA marked by numerous active histone modifications, such as H3K79me2 and H3K4me3, suggesting a role in tumour EMT and progression. The same study showed that a new histone acetyltransferase NAA60, which mediates acetylation events in $\mathrm{H} 4$ such as H4K20ac, H4K79ac and H4K91ac, was silenced in TNBC [97]. Furthermore, a global map of histone $\mathrm{H} 3$ methylation (H3K4me3) and acetylation (H3K4ac) profiles in MDA-MB-231 cells showed an association of H3K4me3 with late-stage cancer cells, while gain of H3K4ac was correlated with cancer-related phenotypic traits, especially EMT pathways [98].

Histone methyltransferases (HMTs) catalyse the methylation of lysine and arginine residues. Genetic modifications of HMTs affect tumour progression and metastasis. Four HMTs (ASH1L, SETDB1, and $S M Y D 3$ ) presented higher amplification frequencies in basal-like breast cancer (a subtype of TNBC) while eight HMT expression levels (EZH1, SMYD3, EHMT1, SETD7, PRDM4, SETD3, SETD1B, and PRDM6) were significantly downregulated and twelve HMT expression levels (EZH2, PRDM15, PRDM13, SMYD2, SMYD5, SUV39H1, SUV39H2, EHMT2, WHSC1, SETD8, SETDB and SETD6) were significantly up-regulated comparing basal-like to other breast cancer subtypes [99].

A multi-parametric RNAi screening approach identified 70 gene candidates involved in EMT. Among them, three histone alteration modulators, histone methyltransferase G9a, H3K79 methylator 
DOT1L and a new histone acetyltransferase KAT5, were shown to be up-regulated, repressing CDH1 and enhancing EMT [100].

DNMTi SGI and HDACi MS275 have been proposed as combined treatment for TNBC able to epigenetically reverse EMT and inhibit cell motility, proliferation and colony formation. This anti-EMT/antitumour activity is exerted by impeding EpCAM cleavage and the WNT pathway, repressing abnormal p53, EZH2, and ZEB1, and by promoting E-cadherin and apoptosis, together with histone $\mathrm{H} 3$ tri-methylation [101].

DNA damage-specific histone chaperone aprataxin PNK-like factor (APLF), significantly enhanced in TNBC, was reported as an essential TNBC biomarker and a treatment target. Downregulation of APLF upregulates E-cadherin (CDH1) expression and suppresses EMT related genes inhibiting MDA-MB-231 cell invasion and metastasis [102].

Based on histone modifications profiling, several studies aimed to reconstitute the normal expression level of epigenetically deregulated genes. For this reason, metastatic TNBC cells have been treated with specific histone modifiers inhibitors to investigate their ability to induce or reduce TNBC metastasis and to evaluate their global effect on the TNBC EMT. Furthermore, the effect of depletion of upregulated histones modifiers on migration and invasive characteristics has been investigated in TNBC metastatic cells. Variations of epithelial and cell adhesion markers were also analysed in order to understand the roles of histone modifications on EMT and, eventually, identify potential diagnostic and prognostic biomarkers.

The role of multiple histone alteration effectors in inducing or reversing EMT in TNBC are listed in Table 3 (see Figure S1). EMT-repressive factors TIP 60 [103] and KDM6A [104] and EMT-inductive factors EZH2 [105], LSD1 [106], hSETD1A [107], JMJD5 [108], KDM5B [109], KDM3A [110] and HDAC8 [111] have been investigated in multiple studies (Table 3 and see Figure S1). Histone modification inhibitors used in studies evaluating the role of specific histone modification treatments in promoting or inhibiting the EMT of TNBC are listed in a supplementary table (Table 4 and see Figure S1). The mechanisms of treatment of the histone deacetylase inhibitors vorinostat (SAHA) [94,112], panobinostat (LBH589) [93], entinostat (ENT) [113,114], trichostatin A (TSA) [115] and HTPB [116], as well as the lysine demethylase inhibitor parnate (PCPA) [117], and the histone methyltransferase inhibitor UNC0638 [118], along with their main role in reversing EMT are listed in Table 4 (see Figure S1).

\section{DNA Methylation}

DNA methylation is the first and the best-described epigenetic modification in tumours characterized by abnormal activity of DNA methyltransferase enzymes (DNMTs), principally DNMT1 [118]. Two main characteristics delineate the cancer epigenome; gene-specific hyper-methylation and global DNA hypo-methylation [119]. Gene-specific hyper methylation of caretaker and tumour suppressor genes is caused by cytosine methylation in CpG islands, which is a recognized epigenetic silencing marker and a key factor in breast carcinogenesis [119-121]. The identification of differentially methylated regions (DMRs) enriched with promoters associated with DNA hypersensitive sites and transcription factor binding sites can be used to sort TNBCs into three different methylation clusters with different prognosis. Three DMRs were associated with good survival, while fourteen DMRs were associated with poor survival [122].

A diverse set of DNA methylation signatures predicting TNBC treatment response, identifying different breast cancer subtypes with significant diagnostic and prognostic potential have been presented by many studies.

First, an association is strongly suggested between the loss of expression of epithelial biomarkers and gene promoter hypermethylation events in human TNBC. Comparison of the hypermethylation of 110 CpGI in 69 cancer-related genes between TNBC and non-TNBC revealed a similar number of methylated CpGI but a different list of methylated genes [123]. 
Table 3. Histone modification factors associated with EMT of TNBC.

\begin{tabular}{|c|c|c|c|c|}
\hline $\begin{array}{l}\text { Histones Modifications } \\
\text { Factors }\end{array}$ & Targets and Pathways & $\begin{array}{c}\text { Sense of } \\
\text { Dyregulation in } \\
\text { TNBC }\end{array}$ & $\begin{array}{l}\text { Role of histone } \\
\text { modifications in } \\
\text { TNBC }\end{array}$ & References \\
\hline $\begin{array}{l}\text { TIP60 } \\
\text { Lysine acetyltransferase }\end{array}$ & $\begin{array}{l}\text { Destabilize DNMT1 and inhibit SNAIL2 function leading to the inhibition of DNA } \\
\text { methylation of EpCAM promoter region activating the expression of epithelial } \\
\text { markers. }\end{array}$ & Downregulated & Anti-tumoural & [103] \\
\hline $\begin{array}{c}\text { KDM6A } \\
\text { H3K27me3-demethylase }\end{array}$ & $\begin{array}{c}\text { Maintenance of CDH1/E-cadherin levels. } \\
\text { Role in the MET-associated resolution. } \\
\text { Reactivation of bivalent genes by removing H3K27me3 } \\
\text { marks deposited during EMT. }\end{array}$ & Downregulated & Anti-tumoural & [104] \\
\hline $\begin{array}{c}\text { LSD1 } \\
\text { Lysine demethylase } 1\end{array}$ & $\begin{array}{l}\text { Represses E-cadherin expression by demethylating H3K4me at gene's promoter, } \\
\text { during which phosphorylation of LSD1 Ser112 is crucial. }\end{array}$ & Up-regulated & Pro-tumoural & [106] \\
\hline $\begin{array}{c}\text { hSETD1A } \\
\text { H3K4 Methyltransferase }\end{array}$ & Activates MMPs expression (MMP2, MMP9, MMP12, MMP13, and MMP17). & Up-regulated & Pro-tumoural & [107] \\
\hline $\begin{array}{c}\text { JMJD5 } \\
\text { H3K36me2 demethylase }\end{array}$ & $\begin{array}{c}\text { Promote cell invasion and induce EMT. } \\
\text { Catalyze Snail promoter H3K36me2 demethylation activating its expression. }\end{array}$ & Up-regulated & Pro-tumoural & [108] \\
\hline $\begin{array}{c}\text { KDM5B } \\
\text { Lysine-specific demethylase } 5 B\end{array}$ & $\begin{array}{l}\text { Overexpress MALAT1. } \\
\text { Overexpress EMT markers, c-Met, Slug and N-Cadherin, and inhibitis E-Cadherin. }\end{array}$ & Up-regulated & Pro-tumoural & [109] \\
\hline $\begin{array}{c}\text { KDM3A } \\
\text { H3 lysine } 9 \text { demethylase } 3 \mathrm{~A} \\
\end{array}$ & $\begin{array}{l}\text { Promotes the expression of invasive genes by erasing H3K9me2 marks. } \\
\text { Regulates the expression of MMP-9 and JUN expressions. }\end{array}$ & not evaluated & Pro-tumoural & [110] \\
\hline $\begin{array}{c}\text { HDAC8 } \\
\text { Zinc-dependent class I HDAC }\end{array}$ & $\begin{array}{l}\text { Enhance TNBC cell migration. } \\
\text { Regulates YAP protein levels by decreasing YAP phosphorylation at Ser127. }\end{array}$ & not evaluated & Pro-tumoural & [111] \\
\hline
\end{tabular}


Table 4. Role of histone modification inhibitors.

\begin{tabular}{|c|c|c|}
\hline Treatment & Mechanisms & References \\
\hline $\begin{array}{l}\text { Panobinostat (LBH589) } \\
\text { Histone deacetylase inhibitor }\end{array}$ & $\begin{array}{c}\text { Increases CDH1 protein expression and morphology changes in MDA-MB-231 cells. } \\
\text { Reverse EMT }\end{array}$ & [93] \\
\hline $\begin{array}{c}\text { Suberoylanilide hydroxamic acid (SAHA) or } \\
\text { Vorinostat } \\
\text { pan-HDAC inhibitor }\end{array}$ & $\begin{array}{c}\text { Suppress metastasis by Inhibiting MMP-9 activity } \\
\text { Promote EMT of TNBC cells via HDAC8/FOXA1 signals } \\
\text { Downregulate E-cadherin } \\
\text { Upregulate N-cadherin, vimentin and fibronectin }\end{array}$ & [94] \\
\hline $\begin{array}{c}\text { Entinostat (ENT) } \\
\text { Class I HDAC (nuclear) inhibitor }\end{array}$ & $\begin{array}{c}\text { Increases E-cadherin transcription } \\
\text { Reduces in N-cadherin mRNA expression } \\
\text { Downregulates snail and twist } \\
\text { Increases vimentin phosphorylation } \\
\text { Increases vimentin filaments's remodeling } \\
\text { Reduces formation of tubulin-based microtentacles } \\
\text { Upregulates cytokerain } 8 / 18 \\
\text { Reverse EMT } \\
\text { Reduce the percentage of TIC cells from TNBC cells. } \\
\text { Reduce the CD44high/ CD24 low cell population, ALDH-1 activity, and protein and mRNA } \\
\text { expression of known TIC markers such as Bmi-1, Nanog, and Oct-4. }\end{array}$ & [113] \\
\hline $\begin{array}{l}\text { Trichostatin A (TSA) } \\
\text { HDAC inhibitor }\end{array}$ & $\begin{array}{c}\text { Reverse EMT } \\
\text { Upregulate E-cadherin and suppresses Slug and Vimentin }\end{array}$ & [115] \\
\hline $\begin{array}{c}\text { HTPB } \\
\text { pan-HDAC inhibitor }\end{array}$ & $\begin{array}{l}\text { Inhibits integrin-b1/FAK/MMP/RhoA/F-actin pathways. } \\
\text { Suppress tumour metastasis }\end{array}$ & [116] \\
\hline $\begin{array}{c}\text { Parnate (PCPA) } \\
\text { Lysine demethylase 1 LSD1 inhibitor }\end{array}$ & $\begin{array}{l}\text { Blockage of Slug/LSD1 interaction } \\
\text { Induces the expression of E-cadherin and other epithelial markers }\end{array}$ & [117] \\
\hline $\begin{array}{c}\text { UNC0638 } \\
\text { Histone methyltransferase inhibitor }\end{array}$ & $\begin{array}{c}\text { Restores E-cadherin and vimentin via modulating the Snail-G9a axis in order to block CSCs } \\
\text { properties and reverse EMT. }\end{array}$ & [118] \\
\hline
\end{tabular}


A specific methylation profile of sixteen cancer-related genes specific to TNBC was defined by the non-methylation of eleven genes (MSH2, MLH1, MSH3, MSH6, CACNA1A, CACNA1G, GSTP1, ID4, PMS2, DLC1, and TWIST1) and the methylation of five genes (RB, CD44, CDKN2B, MGMT, and p73) [123].

Among 38 genes identified as deregulated in TNBC, whole genome DNA methylation analysis revealed an essential role of DNA methylation in modifying the expression of 16 TNBC-specific genes expression. Only IL6ST showed significantly altered methylation in three probes allowing it to be classed as a DMR [124].

The analysis of EMT-related marker expression in TNBC described a new signature for TNBC subclasses, based on the association of CD146 or MCAM expression (an EMT inducer) with the expression of EMT and breast cancer stem cell (BCSC) (CD44+/CD24-) markers, and suggested that ZEB1 expression as a promising biomarker for poor clinical outcome [125].

Aside from DNA methylation inhibition of anti-tumour genes, hypermethylation or hypomethylation of miRNA were responsible for main miRNAs deregulation mentioned above. Addition to the pro-tumour miRNAs up-regulated in TNBC by the absence of methylation, a set of miRNAs displaying anti-tumour characteristics were epigenetically inactivated by DNA methylation (DLK1-DIO3 cluster, miR126, miR195, miR497, miR148a, miR152 and miR-200 family) [126].

A TNBC gene expression signature has been linked to aberrant promoter $C \mathrm{pG}$ hypermethylation of nine epigenetic biomarker genes (CDH1, CEACAM6, CST6, ESR1, GNA11, MUC1, MYB, SCNN1A, and TFF3). The loss or reduced level of methylation-sensitive gene products was defined as a fundamental characteristic of TNBC, and associated with poor long-term survival [127].

Several genes chosen from the DNA-methylation-based profiles were evaluated in separated studies. The impact of epigenetic inactivation was evaluated after methylation of their promoter and correlated to the outcome of metastasis in TNBC invasive cells. Demethylation treatments restoring the expression of target genes changed the progressive character of TNBC cell, allowing the definition of the promoter methylation impact on EMT. The identification of the signalling pathways impacted by this methylation enlightened on target gene functions and may lead to establish novel TNBC gene therapeutic strategies.

Finally, many studies have evaluated the role of DNA methylation in TNBC by inhibiting the regulatory sequences methylation of a number of specific genes. CREB3L1 [128], BRMS1 [129], DACT2 [130], WWC1 [131] and ADAMTS18 [132] with anti-EMT activity were shown to be down-regulated in TNBC, while FOXF2 [133] and DKK2 [134] exerting pro-EMT activity were upregulated in TNBC; suggesting that DNA methylation is a leading source of the expression deregulation and TNBC high metastasis capacity (see Figure S1 and Table 5).

\section{Clinical Trials}

Interpretation of clinical trials related to TNBC remains very complex due to the heterogeneous response to systemic therapy. In the last decade, multiple clinical trials have been conducted to control TNBC growth and metastasis, in order to define new targeted therapies and novel biomarkers. Furthermore, targeting PI3K, AKT, HDAC, PD-1, AR and Hsp 90 in metastatic TNBC with specific inhibitors and antagonists was the topic of a substantial number of clinical trials, including NCT01629615, NCT01790932, NCT02162719, NCT02353988, NCT02457910, NCT02657889, NCT02513472, NCT02768701, NCT02734290, NCT01349959, NCT02898207 and NCT02474173. Moreover, the effect of different drugs such as dasatinib, iniparib, epalrestat, tinostamustine and others was evaluated in various clinical studies NCT00371254, NCT01173497, NCT03244358, and NCT03345485, in the search of therapeutic biomarkers for metastatic TNBC. 
Table 5. DNA modifications implicated in the induction of EMT.

\begin{tabular}{|c|c|c|c|c|}
\hline Genes & Targets and Pathways & $\begin{array}{l}\text { Sense of dyregulation } \\
\text { in TNBC }\end{array}$ & $\begin{array}{l}\text { Role of DNA } \\
\text { methylation in TNBC }\end{array}$ & References \\
\hline $\begin{array}{c}\text { CREB3L1 } \\
\text { Methylation of several key } C p G \text { sites }\end{array}$ & $\begin{array}{c}\text { Metastasis suppressor } \\
\text { Activates p21 expression } \\
\text { Suppresses cancer cell survival and angiogenesis genes. }\end{array}$ & Downregulated & Anti-tumoural & [128] \\
\hline $\begin{array}{c}\text { BRMS1 } \\
\text { Promoter hypermethylation }\end{array}$ & $\begin{array}{l}\text { Metastasis suppressor. } \\
\text { Downregulates several metastasis-related genes through modulating } \\
\text { the activity of NF-kB, including osteopontin (OPN), urokinase-type } \\
\text { plasminogen activator (uPA), micro-RNA-146, interleukin-6 (IL-6) } \\
\text { and chemokine receptor 4 (CXCR4). }\end{array}$ & Downregulated & Anti-tumoural & [129] \\
\hline $\begin{array}{c}\text { DAPPER2 (DACT2) } \\
\text { Promoter } C p G \text { methylation } \\
\end{array}$ & $\begin{array}{l}\text { Metastasis suppressor by antagonizing Wnt/ } \beta \text {-catenin and } \\
\text { Akt/GSK-3 signaling. }\end{array}$ & Downregulated & Anti-tumoural & [130] \\
\hline $\begin{array}{l}\text { WWC1 } \\
\text { H3K27me3 inhibition catalysed by EZH2 } \\
\text { and CpG island methylation mediated by } \\
\text { DNMT1 within the wwo1 promoter }\end{array}$ & $\begin{array}{l}\text { Code for Kibra protein. } \\
\text { EMT suppressor by regulating the Hippo/ YAP tumour suppressor } \\
\text { pathway. }\end{array}$ & Downregulated & Anti-tumoural & [131] \\
\hline $\begin{array}{c}\text { ADAMTS18 } \\
\text { Promoter methylation }\end{array}$ & $\begin{array}{c}\text { Deregulates AKT and NF- } \mathrm{AB} \text { signaling, by inhibiting } \\
\text { phosphorylation levels of AKT and p65. }\end{array}$ & Downregulated & Anti-tumoural & [132] \\
\hline $\begin{array}{c}\text { FOXF2 } \\
\text { Absence of promoter methylation }\end{array}$ & $\begin{array}{l}\text { Functions as a promoter for EMT and metastasis. } \\
\text { Regulates genes involved in controlling cell cycle } \\
\text { progression and EMT, and is co-expressed with EMT genes } \\
\text { SNAI2/Slug and Vimentin and a metastasis-promoting gene GLI2. }\end{array}$ & Up regulated & Pro-tumoural & [133] \\
\hline $\begin{array}{c}\text { DKK2 } \\
\text { promoter } C p G \text { methylation }\end{array}$ & $\begin{array}{c}\text { EMT suppressor by suppressing canonical Wnt/ } \beta \text {-catenin signaling } \\
\text { via inhibiting } \beta \text {-catenin activity. }\end{array}$ & Downregulated & Anti-tumoural & [134] \\
\hline
\end{tabular}


Some authors have tried to revert the triple negative character of TNBC patients in order to give them a chance to benefit from treatments such as trastuzumab (Herceptin ${ }^{\circledR}$ ) or tamoxifen (NCT01194908). It has been demonstrated that ER is not absent in some TNBCs but is epigenetically silenced by several histone and methyl groups leading to its inactivation. Thus, some clinical trials have intended to evaluate the effect of epigenetic reprogramming. Histone deacetylase inhibitors such as LBH589 and demethylating inhibitors can rid of histone- or methyl-group excess; the reactivation of ER opens the door to use hormonal agents in order to control the growth and the metastasis of TNBCs. Despite the number of metastatic TNBC clinical trials every year, drug resistance, wide heterogeneity and high metastasis rate keep TNBC treatment very challenging and epigenetic approaches must be considered and developed.

\section{Conclusions}

Triple negative breast cancer is a heterogeneous entity with a high rate of treatment failure due to the appearance of distant and/or nearby metastases. As a main factor responsible for this invasive capacity, EMT is an interesting prognostic biomarker and therapeutic target for TNBC patients. However, its clinical significance has only recently been investigated. Comprehensive new studies should shed light on EMT-related markers and particularly those implicated in epigenetic mechanisms. Thus, the study of epigenetic alterations in TNBC, encompassing lncRNAs, miRNAs, histone and DNA modifications, is a promising area to develop new treatments and EMT-related biomarkers. It is unlikely however that one epigenetic modification alone would be sufficient to identify robust and potential biomarkers of TNBC. A global study incorporating different epigenetic markers is necessary for understanding their role in TNBC. In conclusion, EMT is a promising anticancer target; its epigenetic alterations can be considered early biomarkers representing potential diagnostic and prognostic factors in order to define a global metastatic signature for TNBC.

Supplementary Materials: The following are available online at http://www.mdpi.com/2072-6694/11/4/559/s1, Figure S1: Interactive network of epigenetic factors driving EMT in Triple Negative Breast Cancers.

Author Contributions: Both authors contributed equally to the writing of this article.

Funding: This research received no external funding.

Acknowledgments: This work is performed within the framework of CPER Epicure 2016 project by the Region Auvergne-Rhone-Alpes and was supported by the "Ligue contre le cancer du Puy de Dôme". We gratefully acknowledge Nancy Uhrhammer for her kind grammatical/spelling review of this paper. We also thank Flora Ponelle-Chachuat for assistance in the generation of the network diagram.

Conflicts of Interest: The authors declare no competing interests.

\section{References}

1. Perou, C.M.; Sørlie, T.; Eisen, M.B.; van de Rijn, M.; Jeffrey, S.S.; Rees, C.A.; Pollack, J.R.; Ross, D.T.; Johnsen, H.; Akslen, L.A.; et al. Molecular portraits of human breast tumours. Nature 2000, 406, 747-752. [CrossRef] [PubMed]

2. Sørlie, T.; Perou, C.M.; Tibshirani, R.; Aas, T.; Geisler, S.; Johnsen, H.; Hastie, T.; Eisen, M.B.; van de Rijn, M.; Jeffrey, S.S.; et al. Gene expression patterns of breast carcinomas distinguish tumor subclasses with clinical implications. Proc. Natl. Acad. Sci. USA 2001, 98, 10869-10874. [CrossRef]

3. He, M.Y.; Rancoule, C.; Rehailia-Blanchard, A.; Espenel, S.; Trone, J.-C.; Bernichon, E.; Guillaume, E.; Vallard, A.; Magné, N. Radiotherapy in triple-negative breast cancer: Current situation and upcoming strategies. Crit. Rev. Oncol. Hematol. 2018, 131, 96-101. [CrossRef]

4. Neelakantan, D.; Zhou, H.; Oliphant, M.U.J.; Zhang, X.; Simon, L.M.; Henke, D.M.; Shaw, C.A.; Wu, M.-F.; Hilsenbeck, S.G.; White, L.D.; et al. EMT cells increase breast cancer metastasis via paracrine GLI activation in neighbouring tumour cells. Nat. Commun. 2017, 8, 15773. [CrossRef] [PubMed]

5. Nieto, M.A.; Huang, R.Y.-J.; Jackson, R.A.; Thiery, J.P. EMT: 2016. Cell 2016, 166, 21-45. [CrossRef] 
6. Hill, B.S.; Sarnella, A.; Capasso, D.; Comegna, D.; Del Gatto, A.; Gramanzini, M.; Albanese, S.; Saviano, M.; Zaccaro, L.; Zannetti, A. Therapeutic Potential of a Novel $\alpha \mathrm{v} \beta 3$ Antagonist to Hamper the Aggressiveness of Mesenchymal Triple Negative Breast Cancer Sub-Type. Cancers 2019, 11, 139. [CrossRef]

7. Camorani, S.; Hill, B.S.; Fontanella, R.; Greco, A.; Gramanzini, M.; Auletta, L.; Gargiulo, S.; Albanese, S.; Lucarelli, E.; Cerchia, L.; et al. Inhibition of Bone Marrow-Derived Mesenchymal Stem Cells Homing Towards Triple-Negative Breast Cancer Microenvironment Using an Anti-PDGFR $\beta$ Aptamer. Theranostics 2017, 7, 3595-3607. [CrossRef] [PubMed]

8. Palazzo, A.F.; Lee, E.S. Non-coding RNA: What is functional and what is junk? Front. Genet. $2015,6,2$. [CrossRef]

9. Kung, J.T.Y.; Colognori, D.; Lee, J.T. Long Noncoding RNAs: Past, Present, and Future. Genetics 2013, 193, 651-669. [CrossRef] [PubMed]

10. Sallam, T.; Sandhu, J.; Tontonoz, P. Long Noncoding RNA Discovery in Cardiovascular Disease: Decoding Form to Function. Circ. Res. 2018, 122, 155-166. [CrossRef] [PubMed]

11. Hauptman, N.; Glavač, D. Long Non-Coding RNA in Cancer. Int. J. Mol. Sci. 2013, 14, 4655-4669. [CrossRef] [PubMed]

12. Zhang, M.; Wu, W.-B.; Wang, Z.-W.; Wang, X.-H. lncRNA NEAT1 is closely related with progression of breast cancer via promoting proliferation and EMT. Eur. Rev. Med. Pharmacol. Sci. 2017, 21, 1020-1026.

13. Tao, S.; He, H.; Chen, Q. Estradiol induces HOTAIR levels via GPER-mediated miR-148a inhibition in breast cancer. J. Transl. Med. 2015, 13, 131. [CrossRef]

14. Cooper, C.; Guo, J.; Yan, Y.; Chooniedass-Kothari, S.; Hube, F.; Hamedani, M.K.; Murphy, L.C.; Myal, Y.; Leygue, E. Increasing the relative expression of endogenous non-coding Steroid Receptor RNA Activator (SRA) in human breast cancer cells using modified oligonucleotides. Nucleic Acids Res. 2009, 37, 4518-4531. [CrossRef]

15. Godinho, M.; Meijer, D.; Setyono-Han, B.; Dorssers, L.C.J.; van Agthoven, T. Characterization of BCAR4, a novel oncogene causing endocrine resistance in human breast cancer cells. J. Cell. Physiol. 2011, 226, 1741-1749. [CrossRef]

16. Lin, A.; Li, C.; Xing, Z.; Hu, Q.; Liang, K.; Han, L.; Wang, C.; Hawke, D.H.; Wang, S.; Zhang, Y.; et al. The LINK-A lncRNA Activates Normoxic HIF1 $\alpha$ Signaling in Triple-negative Breast Cancer. Nat. Cell Biol. 2016, 18, 213-224. [CrossRef] [PubMed]

17. Shen, X.; Xie, B.; Ma, Z.; Yu, W.; Wang, W.; Xu, D.; Yan, X.; Chen, B.; Yu, L.; Li, J.; et al. Identification of novel long non-coding RNAs in triple-negative breast cancer. Oncotarget 2015, 6, 21730-21739. [CrossRef] [PubMed]

18. Yang, F.; Liu, Y.-H.; Dong, S.-Y.; Yao, Z.-H.; Lv, L.; Ma, R.-M.; Dai, X.-X.; Wang, J.; Zhang, X.-H.; Wang, O.-C. Co-expression networks revealed potential core lncRNAs in the triple-negative breast cancer. Gene 2016, 591, 471-477. [CrossRef] [PubMed]

19. Lv, M.; Xu, P.; Wu, Y.; Huang, L.; Li, W.; Lv, S.; Wu, X.; Zeng, X.; Shen, R.; Jia, X.; et al. LncRNAs as new biomarkers to differentiate triple negative breast cancer from non-triple negative breast cancer. Oncotarget 2016, 7, 13047-13059. [CrossRef] [PubMed]

20. Koduru, S.V.; Tiwari, A.K.; Leberfinger, A.; Hazard, S.W.; Kawasawa, Y.I.; Mahajan, M.; Ravnic, D.J. A Comprehensive NGS Data Analysis of Differentially Regulated miRNAs, piRNAs, lncRNAs and sn/snoRNAs in Triple Negative Breast Cancer. J. Cancer 2017, 8, 578-596. [CrossRef] [PubMed]

21. Zhou, C.-X.; Wang, X.; Yang, N.; Xue, S.-K.; Li, W.-C.; Xie, P.-P. LncRNA LET function as a tumor suppressor in breast cancer development. Eur. Rev. Med. Pharmacol. Sci. 2018, 22, 6002-6007. [PubMed]

22. Zheng, R.; Lin, S.; Guan, L.; Yuan, H.; Liu, K.; Liu, C.; Ye, W.; Liao, Y.; Jia, J.; Zhang, R. Long non-coding RNA XIST inhibited breast cancer cell growth, migration, and invasion via miR-155/CDX1 axis. Biochem. Biophys. Res. Commun. 2018, 498, 1002-1008. [CrossRef] [PubMed]

23. Wang, M.; Wang, M.; Wang, Z.; Yu, X.; Song, Y.; Wang, C.; Xu, Y.; Wei, F.; Zhao, Y.; Xu, Y. Long non-coding RNA-CTD-2108O9.1 represses breast cancer metastasis by influencing leukemia inhibitory factor receptor. Cancer Sci. 2018, 109, 1764-1774. [CrossRef] [PubMed]

24. Li, S.; Zhou, J.; Wang, Z.; Wang, P.; Gao, X.; Wang, Y. Long noncoding RNA GAS5 suppresses triple negative breast cancer progression through inhibition of proliferation and invasion by competitively binding miR-196a-5p. Biomed. Pharmacother. 2018, 104, 451-457. [CrossRef] [PubMed] 
25. Jin, C.; Yan, B.; Lu, Q.; Lin, Y.; Ma, L. Reciprocal regulation of Hsa-miR-1 and long noncoding RNA MALAT1 promotes triple-negative breast cancer development. Tumor Biol. 2016, 37, 7383-7394. [CrossRef]

26. Zuo, Y.; Li, Y.; Zhou, Z.; Ma, M.; Fu, K. Long non-coding RNA MALAT1 promotes proliferation and invasion via targeting miR-129-5p in triple-negative breast cancer. Biomed. Pharmacother. 2017, 95, 922-928. [CrossRef]

27. Latorre, E.; Carelli, S.; Raimondi, I.; D’Agostino, V.; Castiglioni, I.; Zucal, C.; Moro, G.; Luciani, A.; Ghilardi, G.; Monti, E.; et al. The Ribonucleic Complex HuR-MALAT1 Represses CD133 Expression and Suppresses Epithelial-Mesenchymal Transition in Breast Cancer. Cancer Res. 2016, 76, 2626-2636. [CrossRef]

28. Wang, Y.-L.; Overstreet, A.-M.; Chen, M.-S.; Wang, J.; Zhao, H.-J.; Ho, P.-C.; Smith, M.; Wang, S.-C. Combined inhibition of EGFR and c-ABL suppresses the growth of triple-negative breast cancer growth through inhibition of HOTAIR. Oncotarget 2015, 6, 11150-11161. [CrossRef]

29. Wang, O.; Yang, F.; Liu, Y.; Lv, L.; Ma, R.; Chen, C.; Wang, J.; Tan, Q.; Cheng, Y.; Xia, E.; et al. C-MYC-induced upregulation of lncRNA SNHG12 regulates cell proliferation, apoptosis and migration in triple-negative breast cancer. Am. J. Transl. Res. 2017, 9, 533-545.

30. Luo, L.; Tang, H.; Ling, L.; Li, N.; Jia, X.; Zhang, Z.; Wang, X.; Shi, L.; Yin, J.; Qiu, N.; et al. LINC01638 lncRNA activates MTDH-Twist1 signaling by preventing SPOP-mediated c-Myc degradation in triple-negative breast cancer. Oncogene 2018, 37, 6166-6179. [CrossRef]

31. Vennin, C.; Spruyt, N.; Dahmani, F.; Julien, S.; Bertucci, F.; Finetti, P.; Chassat, T.; Bourette, R.P.; Le Bourhis, X.; Adriaenssens, E. H19 non coding RNA-derived miR-675 enhances tumorigenesis and metastasis of breast cancer cells by downregulating c-Cbl and Cbl-b. Oncotarget 2015, 6, 29209-29223. [CrossRef] [PubMed]

32. Wang, P.-S.; Chou, C.-H.; Lin, C.-H.; Yao, Y.-C.; Cheng, H.-C.; Li, H.-Y.; Chuang, Y.-C.; Yang, C.-N.; Ger, L.-P.; Chen, Y.-C.; et al. A novel long non-coding RNA linc-ZNF469-3 promotes lung metastasis through miR-574-5p-ZEB1 axis in triple negative breast cancer. Oncogene 2018, 4662-4678. [CrossRef]

33. Xia, E.; Shen, Y.; Bhandari, A.; Zhou, X.; Wang, Y.; Yang, F.; Wang, O. Long non-coding RNA LINC00673 promotes breast cancer proliferation and metastasis through regulating B7-H6 and epithelial-mesenchymal transition. Am. J. Cancer Res. 2018, 8, 1273-1287.

34. Zhang, Y.; Li, J.; Jia, S.; Wang, Y.; Kang, Y.; Zhang, W. Down-regulation of lncRNA-ATB inhibits epithelial-mesenchymal transition of breast cancer cells by increasing miR-141-3p expression. Biochem. Cell Biol. 2019, 97, 193-200. [CrossRef]

35. Li, W.; Jia, G.; Qu, Y.; Du, Q.; Liu, B.; Liu, B. Long Non-Coding RNA (LncRNA) HOXA11-AS Promotes Breast Cancer Invasion and Metastasis by Regulating Epithelial-Mesenchymal Transition. Med. Sci. Monit. 2017, 23, 3393-3403. [CrossRef] [PubMed]

36. Liu, G.; Hu, X.; Zhou, G. Long non-coding RNA OR3A4 promotes proliferation and migration in breast cancer. Biomed. Pharmacother. 2017, 96, 426-433. [CrossRef] [PubMed]

37. Luan, T.; Zhang, X.; Wang, S.; Song, Y.; Zhou, S.; Lin, J.; An, W.; Yuan, W.; Yang, Y.; Cai, H.; et al. Long non-coding RNA MIAT promotes breast cancer progression and functions as ceRNA to regulate DUSP7 expression by sponging miR-155-5p. Oncotarget 2017, 8, 76153-76164. [CrossRef]

38. Song, R.; Zhang, J.; Huang, J.; Hai, T. Long non-coding RNA GHET1 promotes human breast cancer cell proliferation, invasion and migration via affecting epithelial mesenchymal transition. Cancer Biomark. 2018, 22, 565-573. [CrossRef]

39. Li, G.-Y.; Wang, W.; Sun, J.-Y.; Xin, B.; Zhang, X.; Wang, T.; Zhang, Q.-F.; Yao, L.-B.; Han, H.; Fan, D.-M.; et al. Long non-coding RNAs AC026904.1 and UCA1: A “one-two punch" for TGF- $\beta$-induced SNAI2 activation and epithelial-mesenchymal transition in breast cancer. Theranostics 2018, 8, 2846-2861. [CrossRef]

40. Li, Y.; Lv, M.; Song, Z.; Lou, Z.; Wang, R.; Zhuang, M. Long non-coding RNA NNT-AS1 affects progression of breast cancer through miR-142-3p/ZEB1 axis. Biomed. Pharmacother. 2018, 103, 939-946. [CrossRef]

41. Wang, L.; Wang, R.; Ye, Z.; Wang, Y.; Li, X.; Chen, W.; Zhang, M.; Cai, C. PVT1 affects EMT and cell proliferation and migration via regulating p21 in triple-negative breast cancer cells cultured with mature adipogenic medium. Acta Biochim. Biophys. Sin. 2018, 50, 1211-1218. [CrossRef]

42. Yang, F.; Shen, Y.; Zhang, W.; Jin, J.; Huang, D.; Fang, H.; Ji, W.; Shi, Y.; Tang, L.; Chen, W.; et al. An androgen receptor negatively induced long non-coding RNA ARNILA binding to miR-204 promotes the invasion and metastasis of triple-negative breast cancer. Cell Death Differ. 2018, 25, 2209-2220. [CrossRef] [PubMed]

43. Eades, G.; Wolfson, B.; Zhang, Y.; Li, Q.; Yao, Y.; Zhou, Q. lincRNA-RoR and miR-145 regulate invasion in triple-negative breast cancer via targeting ARF6. Mol. Cancer Res. 2015, 13, 330-338. [CrossRef] [PubMed] 
44. Wang, H.-B.; Wei, H.; Wang, J.-S.; Li, L.; Chen, A.-Y.; Li, Z.-G. Down-regulated expression of LINC00518 prevents epithelial cell growth and metastasis in breast cancer through the inhibition of CDX2 methylation and activation of the Wnt signaling pathway. Biochim. Biophys. Acta (BBA) Mol. Basis Dis. 2019, 1865, 708-723. [CrossRef] [PubMed]

45. Huang, X.; Xie, X.; Liu, P.; Yang, L.; Chen, B.; Song, C.; Tang, H.; Xie, X. Adam12 and lnc015192 act as ceRNAs in breast cancer by regulating miR-34a. Oncogene 2018, 37, 6316-6326. [CrossRef] [PubMed]

46. Augoff, K.; McCue, B.; Plow, E.F.; Sossey-Alaoui, K. miR-31 and its host gene lncRNA LOC554202 are regulated by promoter hypermethylation in triple-negative breast cancer. Mol. Cancer 2012, 11, 5. [CrossRef]

47. Lee, J.; Jung, J.H.; Chae, Y.S.; Park, H.Y.; Kim, W.W.; Lee, S.J.; Jeong, J.-H.; Kang, S.H. Long Noncoding RNA snaR Regulates Proliferation, Migration and Invasion of Triple-negative Breast Cancer Cells. Anticancer Res. 2016, 36, 6289-6295. [CrossRef]

48. He, L.; Hannon, G.J. MicroRNAs: Small RNAs with a big role in gene regulation. Nat. Rev. Genet. 2004, 5, 522-531. [CrossRef] [PubMed]

49. Calin, G.A.; Dumitru, C.D.; Shimizu, M.; Bichi, R.; Zupo, S.; Noch, E.; Aldler, H.; Rattan, S.; Keating, M.; Rai, K.; et al. Frequent deletions and down-regulation of micro- RNA genes miR15 and miR16 at $13 q 14$ in chronic lymphocytic leukemia. Proc. Natl. Acad. Sci. USA 2002, 99, 15524-15529. [CrossRef]

50. Kluiver, J.; Poppema, S.; de Jong, D.; Blokzijl, T.; Harms, G.; Jacobs, S.; Kroesen, B.-J.; van den Berg, A. BIC and miR-155 are highly expressed in Hodgkin, primary mediastinal and diffuse large B cell lymphomas. J. Pathol. 2005, 207, 243-249. [CrossRef] [PubMed]

51. Di Leva, G.; Gasparini, P.; Piovan, C.; Ngankeu, A.; Garofalo, M.; Taccioli, C.; Iorio, M.V.; Li, M.; Volinia, S.; Alder, H.; et al. MicroRNA Cluster 221-222 and Estrogen Receptor $\alpha$ Interactions in Breast Cancer. J. Natl. Cancer Inst. 2010, 102, 706-721. [CrossRef]

52. Hayashita, Y.; Osada, H.; Tatematsu, Y.; Yamada, H.; Yanagisawa, K.; Tomida, S.; Yatabe, Y.; Kawahara, K.; Sekido, Y.; Takahashi, T. A polycistronic microRNA cluster, miR-17-92, is overexpressed in human lung cancers and enhances cell proliferation. Cancer Res. 2005, 65, 9628-9632. [CrossRef]

53. Felicetti, F.; Errico, M.C.; Bottero, L.; Segnalini, P.; Stoppacciaro, A.; Biffoni, M.; Felli, N.; Mattia, G.; Petrini, M.; Colombo, M.P.; et al. The promyelocytic leukemia zinc finger-microRNA-221/-222 pathway controls melanoma progression through multiple oncogenic mechanisms. Cancer Res. 2008, 68, 2745-2754. [CrossRef]

54. Calin, G.A.; Sevignani, C.; Dumitru, C.D.; Hyslop, T.; Noch, E.; Yendamuri, S.; Shimizu, M.; Rattan, S.; Bullrich, F.; Negrini, M.; et al. Human microRNA genes are frequently located at fragile sites and genomic regions involved in cancers. Proc. Natl. Acad. Sci. USA 2004, 101, 2999-3004. [CrossRef]

55. Corney, D.C.; Flesken-Nikitin, A.; Godwin, A.K.; Wang, W.; Nikitin, A.Y. MicroRNA-34b and MicroRNA-34c are targets of p53 and cooperate in control of cell proliferation and adhesion-independent growth. Cancer Res. 2007, 67, 8433-8438. [CrossRef]

56. Ding, X.-M. MicroRNAs: Regulators of cancer metastasis and epithelial-mesenchymal transition (EMT). Chin. J. Cancer 2014, 33, 140-147. [CrossRef]

57. Naorem, L.D.; Muthaiyan, M.; Venkatesan, A. Identification of dysregulated miRNAs in triple negative breast cancer: A meta-analysis approach. J. Cell. Physiol. 2018, 234, 11768-11779. [CrossRef] [PubMed]

58. Gasparini, P.; Cascione, L.; Fassan, M.; Lovat, F.; Guler, G.; Balci, S.; Irkkan, C.; Morrison, C.; Croce, C.M.; Shapiro, C.L.; et al. microRNA expression profiling identifies a four microRNA signature as a novel diagnostic and prognostic biomarker in triple negative breast cancers. Oncotarget 2014, 5, 1174-1184. [CrossRef]

59. Yuan, N.; Zhang, G.; Bie, F.; Ma, M.; Ma, Y.; Jiang, X.; Wang, Y.; Hao, X. Integrative analysis of lncRNAs and miRNAs with coding RNAs associated with ceRNA crosstalk network in triple negative breast cancer. OncoTargets Ther. 2017, 10, 5883-5897. [CrossRef] [PubMed]

60. Fkih M'hamed, I.; Privat, M.; Ponelle, F.; Penault-Llorca, F.; Kenani, A.; Bignon, Y.-J. Identification of miR-10b, miR-26a, miR-146a and miR-153 as potential triple-negative breast cancer biomarkers. Cell. Oncol. 2015, 38, 433-442. [CrossRef]

61. Haga, C.L.; Phinney, D.G. MicroRNAs in the Imprinted DLK1-DIO3 Region Repress the Epithelial-to-Mesenchymal Transition by Targeting the TWIST1 Protein Signaling Network. J. Biol. Chem. 2012, 287, 42695-42707. [CrossRef] [PubMed] 
62. Tsouko, E.; Wang, J.; Frigo, D.E.; Aydoğdu, E.; Williams, C. miR-200a inhibits migration of triple-negative breast cancer cells through direct repression of the EPHA2 oncogene. Carcinogenesis 2015, 36, 1051-1060. [CrossRef] [PubMed]

63. Humphries, B.; Wang, Z.; Oom, A.L.; Fisher, T.; Tan, D.; Cui, Y.; Jiang, Y.; Yang, C. MicroRNA-200b targets protein kinase $\mathrm{C} \alpha$ and suppresses triple-negative breast cancer metastasis. Carcinogenesis 2014, 35, 2254-2263. [CrossRef] [PubMed]

64. Damiano, V.; Brisotto, G.; Borgna, S.; di Gennaro, A.; Armellin, M.; Perin, T.; Guardascione, M.; Maestro, R.; Santarosa, M. Epigenetic silencing of miR-200c in breast cancer is associated with aggressiveness and is modulated by ZEB1. Genes Chromosomes Cancer 2017, 56, 147-158. [CrossRef] [PubMed]

65. Wang, X.; Qiu, H.; Tang, R.; Song, H.; Pan, H.; Feng, Z.; Chen, L. miR-30a inhibits epithelial-mesenchymal transition and metastasis in triple-negative breast cancer by targeting ROR1. Oncol. Rep. 2018, 39, 2635-2643. [CrossRef] [PubMed]

66. Liu, Q.; Wang, W.; Yang, X.; Zhao, D.; Li, F.; Wang, H. MicroRNA-146a inhibits cell migration and invasion by targeting RhoA in breast cancer. Oncol. Rep. 2016, 36, 189-196. [CrossRef]

67. Li, D.; Hu, J.; Song, H.; Xu, H.; Wu, C.; Zhao, B.; Xie, D.; Wu, T.; Zhao, J.; Fang, L. miR-143-3p targeting LIM domain kinase 1 suppresses the progression of triple-negative breast cancer cells. Am. J. Transl. Res. 2017, 9, 2276-2285.

68. Li, D.; Wang, H.; Song, H.; Xu, H.; Zhao, B.; Wu, C.; Hu, J.; Wu, T.; Xie, D.; Zhao, J.; et al. The microRNAs $\mathrm{miR}-200 \mathrm{~b}-3 \mathrm{p}$ and miR-429-5p target the LIMK1/CFL1 pathway to inhibit growth and motility of breast cancer cells. Oncotarget 2017, 8, 85276-85289. [CrossRef]

69. Krishnan, K.; Steptoe, A.L.; Martin, H.C.; Pattabiraman, D.R.; Nones, K.; Waddell, N.; Mariasegaram, M.; Simpson, P.T.; Lakhani, S.R.; Vlassov, A.; et al. miR-139-5p is a regulator of metastatic pathways in breast cancer. RNA 2013, 19, 1767-1780. [CrossRef] [PubMed]

70. Lv, Z.-D.; Yang, D.-X.; Liu, X.-P.; Jin, L.-Y.; Wang, X.-G.; Yang, Z.-C.; Liu, D.; Zhao, J.-J.; Kong, B.; Li, F.-N.; et al. MiR-212-5p Suppresses the Epithelial-Mesenchymal Transition in Triple-Negative Breast Cancer by Targeting Prrx2. Cell. Physiol. Biochem. 2017, 44, 1785-1795. [CrossRef] [PubMed]

71. Chen, J.; Shin, V.Y.; Siu, M.T.; Ho, J.C.W.; Cheuk, I.; Kwong, A. miR-199a-5p confers tumor-suppressive role in triple-negative breast cancer. BMC Cancer 2016, 16, 887. [CrossRef]

72. Jang, M.H.; Kim, H.J.; Gwak, J.M.; Chung, Y.R.; Park, S.Y. Prognostic value of microRNA-9 and microRNA-155 expression in triple-negative breast cancer. Hum. Pathol. 2017, 68, 69-78. [CrossRef] [PubMed]

73. Wu, J.; Li, W.-Z.; Huang, M.-L.; Wei, H.-L.; Wang, T.; Fan, J.; Li, N.-L.; Ling, R. Regulation of cancerous progression and epithelial-mesenchymal transition by miR-34c-3p via modulation of MAP3K2 signaling in triple-negative breast cancer cells. Biochem. Biophys. Res. Commun. 2017, 483, 10-16. [CrossRef] [PubMed]

74. Kong, P.; Chen, L.; Yu, M.; Tao, J.; Liu, J.; Wang, Y.; Pan, H.; Zhou, W.; Wang, S. miR-3178 inhibits cell proliferation and metastasis by targeting Notch1 in triple-negative breast cancer. Cell Death Dis. 2018, 9, 1059. [CrossRef] [PubMed]

75. Rhodes, L.V.; Martin, E.C.; Segar, H.C.; Miller, D.F.B.; Buechlein, A.; Rusch, D.B.; Nephew, K.P.; Burow, M.E.; Collins-Burow, B.M. Dual regulation by microRNA-200b-3p and microRNA-200b-5p in the inhibition of epithelial-to-mesenchymal transition in triple-negative breast cancer. Oncotarget 2015, 6, 16638-16652. [CrossRef] [PubMed]

76. Hong, L.; Pan, F.; Jiang, H.; Zhang, L.; Liu, Y.; Cai, C.; Hua, C.; Luo, X.; Sun, J.; Chen, Z. miR-125b inhibited epithelial-mesenchymal transition of triple-negative breast cancer by targeting MAP2K7. OncoTargets Ther. 2016, 9, 2639-2648.

77. Lv, Z.-D.; Kong, B.; Liu, X.-P.; Jin, L.-Y.; Dong, Q.; Li, F.-N.; Wang, H.-B. miR-655 suppresses epithelial-to-mesenchymal transition by targeting Prrx1 in triple-negative breast cancer. J. Cell. Mol. Med. 2016, 20, 864-873. [CrossRef] [PubMed]

78. Wu, J.; Sun, Z.; Sun, H.; Li, Y. MicroRNA-27a promotes tumorigenesis via targeting AKT in triple negative breast cancer. Mol. Med. Rep. 2018, 17, 562-570. [CrossRef]

79. Zhang, X.; Ma, G.; Liu, J.; Zhang, Y. MicroRNA-182 promotes proliferation and metastasis by targeting FOXF2 in triple-negative breast cancer. Oncol. Lett. 2017, 14, 4805-4811. [CrossRef]

80. Liu, H.; Wang, Y.; Li, X.; Zhang, Y.; Li, J.; Zheng, Y.; Liu, M.; Song, X.; Li, X. Expression and regulatory function of miRNA-182 in triple-negative breast cancer cells through its targeting of profilin 1. Tumor Biol. 2013, 34, 1713-1722. [CrossRef] 
81. Li, Q.; Liu, J.; Meng, X.; Pang, R.; Li, J. MicroRNA-454 may function as an oncogene via targeting AKT in triple negative breast cancer. J. Biol. Res. 2017, 24, 10. [CrossRef]

82. Chen, D.; Dang, B.-L.; Huang, J.; Chen, M.; Wu, D.; Xu, M.-L.; Li, R.; Yan, G.-R. MiR-373 drives the epithelial-to-mesenchymal transition and metastasis via the miR-373-TXNIP-HIF1 $\alpha$-TWIST signaling axis in breast cancer. Oncotarget 2015, 6, 32701-32712.

83. Hwang, M.S.; Yu, N.; Stinson, S.Y.; Yue, P.; Newman, R.J.; Allan, B.B.; Dornan, D. miR-221/222 Targets Adiponectin Receptor 1 to Promote the Epithelial-to-Mesenchymal Transition in Breast Cancer. PLoS ONE 2013, 8, e66502. [CrossRef]

84. Han, X.; Yan, S.; Weijie, Z.; Feng, W.; Liuxing, W.; Mengquan, L.; Qingxia, F. Critical role of miR-10b in transforming growth factor- $\beta 1$-induced epithelial-mesenchymal transition in breast cancer. Cancer Gene Ther. 2014, 21, 60-67. [CrossRef]

85. Chen, M.; Wei, L.; Law, C.-T.; Tsang, F.H.-C.; Shen, J.; Cheng, C.L.-H.; Tsang, L.-H.; Ho, D.W.-H.; Chiu, D.K.-C.; Lee, J.M.-F.; et al. RNA N6-methyladenosine methyltransferase-like 3 promotes liver cancer progression through YTHDF2-dependent posttranscriptional silencing of SOCS2. Hepatology 2018, 67, 2254-2270. [CrossRef]

86. Lv, D.; Jia, F.; Hou, Y.; Sang, Y.; Alvarez, A.A.; Zhang, W.; Gao, W.-Q.; Hu, B.; Cheng, S.-Y.; Ge, J.; et al. Histone acetyltransferase KAT6A upregulates PI3K/AKT signaling through TRIM24 binding. Cancer Res. 2017, 77, 6190-6201. [CrossRef]

87. Audia, J.E.; Campbell, R.M. Histone Modifications and Cancer. Cold Spring Harb. Perspect. Biol. $2016,8$. [CrossRef]

88. Michalak, E.M.; Visvader, J.E. Dysregulation of histone methyltransferases in breast cancer-Opportunities for new targeted therapies? Mol. Oncol. 2016, 10, 1497-1515. [CrossRef]

89. Wang, Z.-T.; Chen, Z.-J.; Jiang, G.-M.; Wu, Y.-M.; Liu, T.; Yi, Y.-M.; Zeng, J.; Du, J.; Wang, H.-S. Histone deacetylase inhibitors suppress mutant p53 transcription via HDAC8/YY1 signals in triple negative breast cancer cells. Cell. Signal. 2016, 28, 506-515. [CrossRef] [PubMed]

90. Lewis, K.A.; Jordan, H.R.; Tollefsbol, T.O. Effects of SAHA and EGCG on Growth Potentiation of Triple-Negative Breast Cancer Cells. Cancers 2019, 11, 23. [CrossRef]

91. Manna, P.R.; Ahmed, A.U.; Vartak, D.; Molehin, D.; Pruitt, K. Overexpression of the steroidogenic acute regulatory protein in breast cancer: Regulation by histone deacetylase inhibition. Biochem. Biophys. Res. Commun. 2019, 509, 476-482. [CrossRef]

92. Fedele, P.; Orlando, L.; Cinieri, S. Targeting triple negative breast cancer with histone deacetylase inhibitors. Expert Opin. Investig. Drugs 2017, 26, 1199-1206. [CrossRef]

93. Tate, C.R.; Rhodes, L.V.; Segar, H.C.; Driver, J.L.; Pounder, F.N.; Burow, M.E.; Collins-Burow, B.M. Targeting triple-negative breast cancer cells with the histone deacetylase inhibitor panobinostat. Breast Cancer Res. 2012, 14, R79. [CrossRef]

94. Chiu, H.-W.; Yeh, Y.-L.; Wang, Y.-C.; Huang, W.-J.; Ho, S.-Y.; Lin, P.; Wang, Y.-J. Combination of the novel histone deacetylase inhibitor YCW1 and radiation induces autophagic cell death through the downregulation of BNIP3 in triple-negative breast cancer cells in vitro and in an orthotopic mouse model. Mol. Cancer 2016, 15, 46. [CrossRef] [PubMed]

95. Carlisi, D.; Lauricella, M.; D'Anneo, A.; Buttitta, G.; Emanuele, S.; di Fiore, R.; Martinez, R.; Rolfo, C.; Vento, R.; Tesoriere, G. The synergistic effect of SAHA and parthenolide in MDA-MB231 breast cancer cells. J. Cell. Physiol. 2015, 230, 1276-1289. [CrossRef] [PubMed]

96. Zhang, G.; Park, M.A.; Mitchell, C.; Hamed, H.; Rahmani, M.; Martin, A.P.; Curiel, D.T.; Yacoub, A.; Graf, M.; Lee, R.; et al. Vorinostat and sorafenib synergistically kill tumor cells via FLIP suppression and CD95 activation. Clin. Cancer Res. 2008, 14, 5385-5399. [CrossRef]

97. Xi, Y.; Shi, J.; Li, W.; Tanaka, K.; Allton, K.L.; Richardson, D.; Li, J.; Franco, H.L.; Nagari, A.; Malladi, V.S.; et al. Histone modification profiling in breast cancer cell lines highlights commonalities and differences among subtypes. BMC Genom. 2018, 19, 150. [CrossRef]

98. Messier, T.L.; Gordon, J.A.R.; Boyd, J.R.; Tye, C.E.; Browne, G.; Stein, J.L.; Lian, J.B.; Stein, G.S. Histone H3 lysine 4 acetylation and methylation dynamics define breast cancer subtypes. Oncotarget 2016, 7, 5094-5109. [CrossRef] [PubMed]

99. Liu, L.; Kimball, S.; Liu, H.; Holowatyj, A.; Yang, Z.-Q. Genetic alterations of histone lysine methyltransferases and their significance in breast cancer. Oncotarget 2014, 6, 2466-2482. [CrossRef] [PubMed] 
100. Gregoire, J.-M.; Fleury, L.; Salazar-Cardozo, C.; Alby, F.; Masson, V.; Arimondo, P.B.; Ausseil, F. Identification of epigenetic factors regulating the mesenchyme to epithelium transition by RNA interference screening in breast cancer cells. BMC Cancer 2016, 16, 700. [CrossRef] [PubMed]

101. Su, Y.; Hopfinger, N.R.; Nguyen, T.D.; Pogash, T.J.; Santucci-Pereira, J.; Russo, J. Epigenetic reprogramming of epithelial mesenchymal transition in triple negative breast cancer cells with DNA methyltransferase and histone deacetylase inhibitors. J. Exp. Clin. Cancer Res. 2018, 37, 1848-1857. [CrossRef]

102. Majumder, A.; Syed, K.M.; Mukherjee, A.; Lankadasari, M.B.; Azeez, J.M.; Sreeja, S.; Harikumar, K.B.; Pillai, M.R.; Dutta, D. Enhanced expression of histone chaperone APLF associate with breast cancer. Mol. Cancer 2018, 17, 76. [CrossRef] [PubMed]

103. Zhang, Y.; Subbaiah, V.K.; Rajagopalan, D.; Tham, C.Y.; Abdullah, L.N.; Toh, T.B.; Gong, M.; Tan, T.Z.; Jadhav, S.P.; Pandey, A.K.; et al. TIP60 inhibits metastasis by ablating DNMT1-SNAIL2-driven epithelial-mesenchymal transition program. J. Mol. Cell Biol. 2016, 8, 384-399. [CrossRef]

104. Taube, J.H.; Sphyris, N.; Johnson, K.S.; Reisenauer, K.N.; Nesbit, T.A.; Joseph, R.; Vijay, G.V.; Sarkar, T.R.; Bhangre, N.A.; Song, J.J.; et al. The H3K27me3-demethylase KDM6A is suppressed in breast cancer stem-like cells, and enables the resolution of bivalency during the mesenchymal-epithelial transition. Oncotarget 2017, 8, 65548-65565. [CrossRef] [PubMed]

105. Chien, Y.-C.; Liu, L.-C.; Ye, H.-Y.; Wu, J.-Y.; Yu, Y.-L. EZH2 promotes migration and invasion of triple-negative breast cancer cells via regulating TIMP2-MMP-2/-9 pathway. Am. J. Cancer Res. 2018, 8, 422-434. [PubMed]

106. Feng, J.; Xu, G.; Liu, J.; Zhang, N.; Li, L.; Ji, J.; Zhang, J.; Zhang, L.; Wang, G.; Wang, X.; et al. Phosphorylation of LSD1 at Ser112 is crucial for its function in induction of EMT and metastasis in breast cancer. Breast Cancer Res. Treat. 2016, 159, 443-456. [CrossRef]

107. Salz, T.; Deng, C.; Pampo, C.; Siemann, D.; Qiu, Y.; Brown, K.; Huang, S. Histone Methyltransferase hSETD1A Is a Novel Regulator of Metastasis in Breast Cancer. Mol. Cancer Res. 2015, 13, 461-469. [CrossRef]

108. Zhao, Z.; Sun, C.; Li, F.; Han, J.; Li, X.; Song, Z. Overexpression of histone demethylase JMJD5 promotes metastasis and indicates a poor prognosis in breast cancer. Int. J. Clin. Exp. Pathol. 2015, 8, 10325-10334.

109. Bamodu, O.A.; Huang, W.-C.; Lee, W.-H.; Wu, A.; Wang, L.S.; Hsiao, M.; Yeh, C.-T.; Chao, T.-Y. Aberrant KDM5B expression promotes aggressive breast cancer through MALAT1 overexpression and downregulation of hsa-miR-448. BMC Cancer 2016, 16, 160. [CrossRef]

110. Ramadoss, S.; Guo, G.; Wang, C.-Y. Lysine demethylase KDM3A regulates breast cancer cell invasion and apoptosis by targeting histone and the non-histone protein p53. Oncogene 2017, 36, 47-59. [CrossRef]

111. An, P.; Li, J.; Lu, L.; Wu, Y.; Ling, Y.; Du, J.; Chen, Z.; Wang, H. Histone deacetylase 8 triggers the migration of triple negative breast cancer cells via regulation of YAP signals. Eur. J. Pharmacol. 2018, 845, 16-23. [CrossRef]

112. Wu, S.; Luo, Z.; Yu, P.-J.; Xie, H.; He, Y.-W. Suberoylanilide hydroxamic acid (SAHA) promotes the epithelial mesenchymal transition of triple negative breast cancer cells via HDAC8/FOXA1 signals. Biol. Chem. 2016, 397, 75-83. [CrossRef]

113. Shah, P.; Gau, Y.; Sabnis, G. Histone deacetylase inhibitor entinostat reverses epithelial to mesenchymal transition of breast cancer cells by reversing the repression of E-cadherin. Breast Cancer Res. Treat. 2014, 143, 99-111. [CrossRef]

114. Schech, A.; Kazi, A.; Yu, S.; Shah, P.; Sabnis, G. Histone Deacetylase Inhibitor Entinostat Inhibits Tumor-Initiating Cells in Triple-Negative Breast Cancer Cells. Mol. Cancer Ther. 2015, 14, 1848-1857. [CrossRef]

115. Rahimian, A.; Barati, G.; Mehrandish, R.; Mellati, A.A. Inhibition of Histone Deacetylases Reverses Epithelial-Mesenchymal Transition in Triple-Negative Breast Cancer Cells through a Slug Mediated Mechanism. Mol. Biol. 2018, 52, 474-481. [CrossRef]

116. Shieh, J.-M.; Wei, T.-T.; Tang, Y.-A.; Huang, S.-M.; Wen, W.-L.; Chen, M.-Y.; Cheng, H.-C.; Salunke, S.B.; Chen, C.-S.; Lin, P.; et al. Mitochondrial Apoptosis and FAK Signaling Disruption by a Novel Histone Deacetylase Inhibitor, HTPB, in Antitumor and Antimetastatic Mouse Models. PLoS ONE 2012, 7, e30240. [CrossRef]

117. Ferrari-Amorotti, G.; Chiodoni, C.; Shen, F.; Cattelani, S.; Soliera, A.R.; Manzotti, G.; Grisendi, G.; Dominici, M.; Rivasi, F.; Colombo, M.P.; et al. Suppression of Invasion and Metastasis of Triple-Negative Breast Cancer Lines by Pharmacological or Genetic Inhibition of Slug Activity. Neoplasia 2014, 16, 1047-1058. [CrossRef] 
118. Liu, X.-R.; Zhou, L.-H.; Hu, J.-X.; Liu, L.-M.; Wan, H.-P.; Zhang, X.-Q. UNC0638, a G9a inhibitor, suppresses epithelial-mesenchymal transition-mediated cellular migration and invasion in triple negative breast cancer. Mol. Med. Rep. 2018, 17, 2239. [CrossRef]

119. Hirst, M.; Marra, M.A. Epigenetics and human disease. Int. J. Biochem. Cell Biol. 2009, 41, 136-146. [CrossRef]

120. Esteller, M. CpG island hypermethylation and tumor suppressor genes: A booming present, a brighter future. Oncogene 2002, 21, 5427-5440. [CrossRef]

121. Jing, F.; Yuping, W.; Yong, C.; Jie, L.; Jun, L.; Xuanbing, T.; Lihua, H. CpG island methylator phenotype of multigene in serum of sporadic breast carcinoma. Tumor Biol. 2010, 31, 321-331. [CrossRef] [PubMed]

122. Stirzaker, C.; Zotenko, E.; Song, J.Z.; Qu, W.; Nair, S.S.; Locke, W.J.; Stone, A.; Armstong, N.J.; Robinson, M.D.; Dobrovic, A.; et al. Methylome sequencing in triple-negative breast cancer reveals distinct methylation clusters with prognostic value. Nat. Commun. 2015, 6, 5899. [CrossRef]

123. Branham, M.T.; Marzese, D.M.; Laurito, S.R.; Gago, F.E.; Orozco, J.I.; Tello, O.M.; Vargas-Roig, L.M.; Roqué, M. Methylation profile of triple-negative breast carcinomas. Oncogenesis 2012, 1, e17. [CrossRef]

124. Mathe, A.; Wong-Brown, M.; Locke, W.J.; Stirzaker, C.; Braye, S.G.; Forbes, J.F.; Clark, S.J.; Avery-Kiejda, K.A.; Scott, R.J. DNA methylation profile of triple negative breast cancer-specific genes comparing lymph node positive patients to lymph node negative patients. Sci. Rep. 2016, 6, 33435. [CrossRef]

125. Jang, M.H.; Kim, H.J.; Kim, E.J.; Chung, Y.R.; Park, S.Y. Expression of epithelial-mesenchymal transition-related markers in triple-negative breast cancer: ZEB1 as a potential biomarker for poor clinical outcome. Hum. Pathol. 2015, 46, 1267-1274. [CrossRef]

126. Ramassone, A.; Pagotto, S.; Veronese, A.; Visone, R. Epigenetics and MicroRNAs in Cancer. Int. J. Mol. Sci. 2018, 19, 459. [CrossRef]

127. Roll, J.D.; Rivenbark, A.G.; Sandhu, R.; Parker, J.S.; Jones, W.D.; Carey, L.A.; Livasy, C.A.; Coleman, W.B. Dysregulation of the epigenome in triple-negative breast cancers: Basal-like and claudin-low breast cancers express aberrant DNA hypermethylation. Exp. Mol. Pathol. 2013, 95, 276-287. [CrossRef]

128. Ward, A.K.; Mellor, P.; Smith, S.E.; Kendall, S.; Just, N.A.; Vizeacoumar, F.S.; Sarker, S.; Phillips, Z.; Alvi, R.; Saxena, A.; et al. Epigenetic silencing of CREB3L1 by DNA methylation is associated with high-grade metastatic breast cancers with poor prognosis and is prevalent in triple negative breast cancers. Breast Cancer Res. 2016, 18, 12. [CrossRef]

129. Kong, B.; Lv, Z.-D.; Wang, Y.; Jin, L.-Y.; Ding, L.; Yang, Z.-C. Down-regulation of BRMS1 by DNA hypermethylation and its association with metastatic progression in triple-negative breast cancer. Int. J. Clin. Exp. Pathol. 2015, 8, 11076-11083.

130. Xiang, T.; Fan, Y.; Li, C.; Li, L.; Ying, Y.; Mu, J.; Peng, W.; Feng, Y.; Oberst, M.; Kelly, K.; et al. DACT2 silencing by promoter $\mathrm{CPG}$ methylation disrupts its regulation of epithelial-to-mesenchymal transition and cytoskeleton reorganization in breast cancer cells. Oncotarget 2016, 7, 70924-70935. [CrossRef]

131. Liu, X.; Li, C.; Zhang, R.; Xiao, W.; Niu, X.; Ye, X.; Li, Z.; Guo, Y.; Tan, J.; Li, Y. The EZH2- H3K27me3-DNMT1 complex orchestrates epigenetic silencing of the wwc1 gene, a Hippo/YAP pathway upstream effector, in breast cancer epithelial cells. Cell. Signal. 2018, 51, 243-256. [CrossRef]

132. Xu, H.; Xiao, Q.; Fan, Y.; Xiang, T.; Li, C.; Li, C.; Li, S.; Hui, T.; Zhang, L.; Li, H.; et al. Epigenetic silencing of ADAMTS18 promotes cell migration and invasion of breast cancer through AKT and NF- $\mathrm{KB}$ signaling. Cancer Med. 2017, 6, 1399-1408. [CrossRef]

133. Lo, P.-K.; Lee, J.S.; Liang, X.; Sukumar, S. The dual role of FOXF2 in regulation of DNA replication and the epithelial-mesenchymal transition in breast cancer progression. Cell. Signal. 2016, 28, 1502-1519. [CrossRef]

134. Mu, J.; Hui, T.; Shao, B.; Li, L.; Du, Z.; Lu, L.; Ye, L.; Li, S.; Li, Q.; Xiao, Q.; et al. Dickkopf-related protein 2 induces G0/G1 arrest and apoptosis through suppressing Wnt/ $\beta$-catenin signaling and is frequently methylated in breast cancer. Oncotarget 2017, 8, 39443-39459. [CrossRef]

(C) 2019 by the authors. Licensee MDPI, Basel, Switzerland. This article is an open access article distributed under the terms and conditions of the Creative Commons Attribution (CC BY) license (http://creativecommons.org/licenses/by/4.0/). 